\title{
APPLICATION OF LES, PANS AND RANS TO A CASE OF INTAKE CHANNEL STEADY FLOW TEST BENCH
}

\section{OLDŘICH VÍTEK, RADEK TICHÁNEK, PETR HATSCHBACH}

Czech Technical University in Prague, Department of Automotive, Combustion Engine and Railway Engineering, Technická 4, CZ 16607 Prague 6, Czech Republic, Tel +420224352507, Fax +420224352500, Email: Oldrich.Vitek@fs.cvut.cz

\section{SHRNUTí}

Článek se zabývá vyhodnocením průtokových vlastností (průtokový součinitel, součinitel prǐčné a tečné rotace) sacího kanálu užitím jak 3-D CFD simulace, tak měření. Byla provedena citlivostní studie různých parametrů simulace. Nejdůležitější jsou vlastnosti sítě a použité modely turbulence (uvažované modely: LES, PANS a RANS). Co se týká sítě, tak kritickým parametrem je konfigurace v těsné blízkosti stěny - tlouštka a počet vrstev těsně u stěny mají velký vliv na průtok, avšak součinitele přičné a tečné rotace na tom téměř nezávisí. Odtud plyne, že tyto parametry sítě lze považovat za ladící parametry CFD modelu. Co se týká velikosti oka sítě, 2 velikosti byly testovány $(0.6$ a $0.3 \mathrm{~mm})$. Ukázalo se, že ani jedna z těchto sítí není dostatečně jemná pro korektní aplikaci LES. A tedy PANS funguje spiše jako RANS. Z hlediska modelů turbulence je PANS jeví jako nejlepší možnost, protože kombinuje výhody jak LES, tak RANS. Obecně je možné konstatovat, že Ize dosáhnout relativně dobré shody na průtoku, ale součinitele príčné a tečné rotace jsou problematické, nebot' byla dosažena pouze kvalitativní shoda.

\section{KLIČCVÁ SLOVA: PRŮTOKOVÝ SOUČINITEL, ČISLO TEČNÉ ROTACE, ČÍSLO PŘÍČNÉ ROTACE, MODELOVÁNÍ TURBULENCE,} LES, PANS, RANS

\section{ABSTRACT}

The paper deals with evaluation of intake channel flow properties (discharge coefficient, tumble and swirl ratio) using both 3-D CFD simulation and measurement. Sensitivity of different calculation parameters was tested. The most important ones are mesh parameters and applied turbulence models (considered models: LES, PANS and RANS). Concerning the mesh, the critical parameter is a mesh configuration near a wall - a thickness of mesh boundary layer and an amount of these layers have significant impact on mass flow rate while tumble/swirl ratio is unaffected by that. Based on that, these mesh parameters can be considered as tuning constants for fine-tuning the CFD model. Regarding the mesh cell size, 2 different values were tested $(0.6$ and $0.3 \mathrm{~mm})$. It was found out that neither mesh is fine enough to perform proper LES. Hence, PANS performance is close to RANS. Concerning the turbulence models, PANS seems to be the best one as it combines advantages of both LES and RANS. Generally speaking, mass flow rate prediction is relatively good while swirl/tumble one is more problematic as only qualitative agreement can be achieved.

KEYWORDS: DISCHARGE COEFFICIENT, SWIRL NUMBER, TUMBLE NUMBER, TURBULENCE MODELLING, LES, PANS, RANS

\section{INTRODUCTION}

Gas exchange phase of 4-stroke internal combustion engine (ICE) is very important in terms of following engine cycle phases (compression and combustion). Moreover, it is a critical parameter in terms of engine volumetric efficiency, turbulence level and formation of large-scale coherent structure(s). Hence, the ability to model that properly is important when optimizing engine design of intake manifold and intake valve timing. However, gas exchange phase is a strongly dynamic process this causes problems when evaluating that under typical engine operating conditions. Based on that, a steady flow test bench case is a typical common approach to evaluate intake/exhaust channel properties in terms of flow rate and vortex formation. The whole system of intake/exhaust channel and intake/exhaust valve at a specific position (which is constant with respect to time) is measured under steady boundary conditions.

It is well known that prediction of both flow rate and vortex formation is a challenging task for 3-D CFD. Typically, the flow rate can be predicted reasonably well while vortex formation is usually captured only qualitatively. Hence, there is still a potential of significant improvement of simulation results. 
The paper deals with application of new simulation techniques (LES and PANS) to test their ability to predict steady flow test bench results - brief description of both LES and PANS is provided in the Appendix section at the end of the paper. The main goal is to compare simulation results with experimental data while using both a standard modelling approach (RANS) and new ones (LES, PANS). Only intake channels are considered in the paper. The experimental data were available for automotive SI engine (c.f. Table 1) at 2 different configurations - both intake valves are open (typical SI engine operation) and single intake valve is open. The following parameters were measured - discharge coefficient, tumble number and swirl number. The same cases were modelled and the simulation results were compared with experimental data.

\section{MATHEMATICAL MODEL}

Mathematical model is based on existing engine geometry (c.f. Table 1) and commercial 3-D CFD SW tool AVL FIRE [14]. Geometry corresponds exactly to the layout/configuration of experimental device (c.f. section Measurement and Experimental Data). 3-D CAD data of engine cylinder head were provided by engine manufacturer. All the necessary geometry information was available, hence the meshing procedure could be started.

The meshing itself was made by means of hybrid meshing tool of AVL FIRE. Typical mesh cell size was set to $0.6 \mathrm{~mm}$ - this is based on experience from the previous work $[12,13]$ with LES approach and the value concerns (due to total amount of mesh cells) important regions of considered geometry only (intake port upstream of valve seat, valve seat area, cylinder area near the cylinder head). The same mesh was applied to all considered turbulence models. However, local refinement was used at certain locations of considered geometry (c.f. Figure 1) - the local mesh refinement was applied using the authors' experience with similar cases and applying recommendations of SW provider. This especially concerns mesh parameters in the near-wall regions. The meshing itself is a time consuming process - application of macros allowed significant shortening of these times as a lot of meshes had to be created. The methodology was the same all the time - the only difference is a valve lift. The same approach was applied for the case of fine mesh as well. The important parameters of applied meshes are summarized in Table 2.

It was found out that mesh setting of near-wall regions is critically important. There are 2 main parameters to control that - the height (in direction perpendicular to the wall) of a cell in a single layer and the number of these layers (the near-wall mesh layers are usually called the 'boundary layers'). Hence, variations of these parameters was tested (Table 2).

Regarding turbulence models, 3 different approaches were applied - classical RANS one using AVL's 3-euqation k-z-f model

\begin{tabular}{|lcc|}
\hline Engine Parameter & Unit & Value \\
\hline Bore-to-Stroke Ratio & {$[1]$} & 0.880 \\
\hline Compression Ratio & {$[1]$} & 10.2 \\
\hline Charging & & Naturally Aspirated \\
\hline Fuel & & Gasoline (ON 95) \\
\hline Number of Intake Valves & 2 \\
\hline Number of Exhaust Valves & 2 \\
\hline
\end{tabular}

TABLE 1: Main engine parameters.

TABULKA 1: Hlavní parametry motoru.

\begin{tabular}{|lccc|}
\hline Parameter & Unit & Standard Mesh & Fine Mesh \\
\hline Typical Mesh Size & {$[\mathrm{mm}]$} & 0.6 & 0.3 \\
\hline Amount of Mesh Cells & {$[1]$} & 5.9 & 16.7 \\
\hline Share of Hex Cells & {$[\%]$} & 96 & 99 \\
\hline Number of BL layers & {$[1]$} & 3 and 4 & 4 \\
\hline BL Thickness & {$[\mathrm{mm}]$} & $0.06-0.15$ & 0.1 \\
\hline
\end{tabular}

TABLE 2: Main mesh parameters.

TABULKA 2: Hlavní parametry sítě.

\begin{tabular}{|c|c|c|}
\hline Engine Parameter & Unit & Value \\
\hline Simulation Mode & & Unsteady \\
\hline Turbulence Models & & LES, PANS, RANS \\
\hline Time Accuracy Order & & 1st, 2nd \\
\hline Space Accuracy Order & & 2nd \\
\hline Numerical Method & & SIMPLE \\
\hline Linear Solver & & GSTB \\
\hline Convergence Criteria (Norm. Resid.) & & $<0.0001$ \\
\hline
\end{tabular}

TABLE 3: Main parameters of calculation setup.

TABULKA 3: Hlavní parametry nastavení výpočtu.

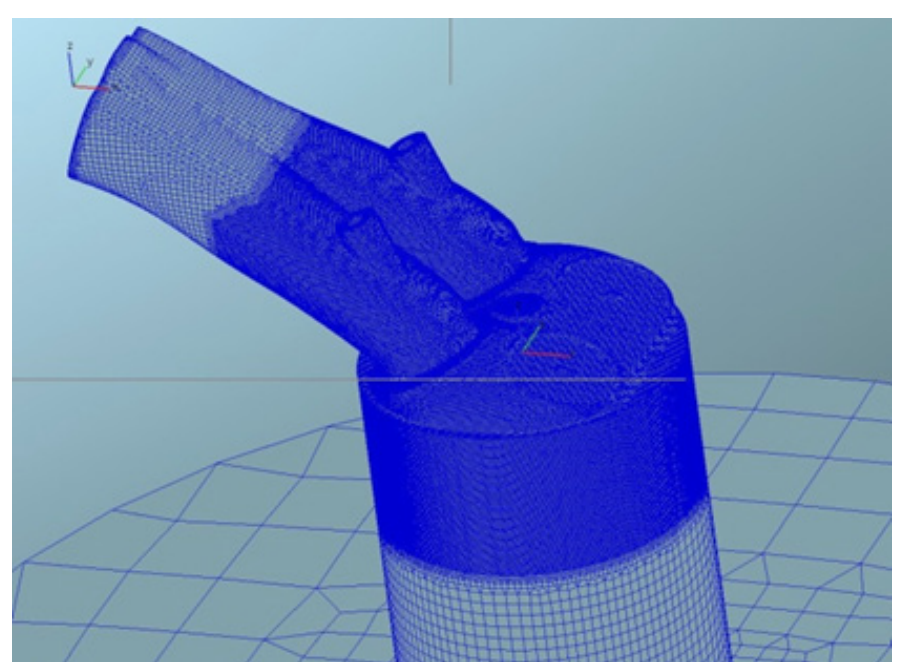

FIGURE 1: Example of applied mesh.

OBRÁZEK 1: Př́klad použité sítě. 
$[1,2,3]$, the LES one $[4,5,6,7,8,14]$ using Smagorinsky model (and in some cases, dynamic LES-CSM one) and the PANS one $[9,10,11]$. Concerning boundary conditions, they correspond to measurement setup - the most important one is the pressure difference between inlet and outlet, which was constant at the value of $5 \mathrm{kPa}$ for all cases. Other important model parameters (discretization schemes, under-relaxation factors, linear solver setting, etc.) were set using the authors' experience and SW provider recommendations. Important parameters of the calculation setup are summarized in Table 3.

\section{MEASUREMENT}

\section{AND EXPERIMENTAL DATA}

The steady flow testing was used to characterize the flow capacity and the in-cylinder flow pattern. A schematic drawing of the steady flow test rig is shown in Figure 2. A cylinder head with a dummy cylinder (diameter is equal to the engine bore) is placed on the settling tank. The Roots blower with speed control and bypass flow control is employed to suck the air through the test rig. Pressure drop in the tank is set to $4.9 \mathrm{kPa}$ relative to atmospheric pressure that ensures that the flow is fully turbulent. The mass flow rate is measured with orifice plate flowmeter.

The flow coefficient $\mu_{\sigma}$ is calculated as the ratio of the measured mass flow rate to the theoretically calculated flow rate through a reference flow area:

$$
\mu \sigma=\frac{\dot{m}_{\text {meas }}}{\dot{m}_{\text {theor }}}
$$

Reference flow area is the valve inner seat area, where $d_{v}$ is inner diameter of the valve seat. The flow coefficient $\mu_{\sigma}$ is equal to value of discharge coefficient $C_{D}$ used in the GT-Power used with a reference area (c.f. the GT-SUITE [15] Flow Theory Manual, ch. 2.2.7. Discharge Coefficients).

The honeycomb torquemeter is used for swirl in-cylinder motion characterization. Supposing that the cylinder charge is a solid rotating body with diameter equal to cylinder bore, the swirl number is calculated as the ratio of the equivalent swirl vortex rotation to the fictitious engine speed:

$\frac{n_{j t}}{n}=\frac{2 \cdot \rho \cdot Z \cdot B_{S}}{\dot{m}_{\text {meas }}^{2}}$

Where $\mathrm{Q}$ is density, $\mathrm{Z}$ is stroke, $\mathrm{B}_{\mathrm{s}}$ angular momentum flux of swirl (directly measured by torquemeter).

This is the same definition like the AVL (Tippelmann) definition of stationary swirl number. For swirl coefficient $C_{s^{\prime}}$ which is used in the GT-Power (c.f. the GT-SUITE [15] Engine Performance Application Manual, ch. 2.5.2. Swirl and Tumble) it is necessary to apply the following transformation equation:
$C_{s}=\frac{i_{v} \cdot \frac{\pi \cdot d_{v}^{2}}{4} \cdot \mu \sigma}{D \cdot Z} \cdot\left(\frac{n_{j t}}{n}\right)$

Where $i_{V}$ is number of valves, $D$ is bore.

Tumblemeter of in-house design is used for in-cylider tumble level measurement - c.f. Figure 3. A fine square mesh in a circular bracket with the shaft perpendicular to the axis of the cylinder is inserted into the cylinder. The torque required to maintain the mesh in a position perpendicular to the cylinder is measured. Measured torque is proportional to tumble component of the angular momentum. Quantity and position of tumble angular momentum is evaluated from 8 measurements with rotation of the cylinder head relative to the mesh bracket axis with step of 45 degrees.

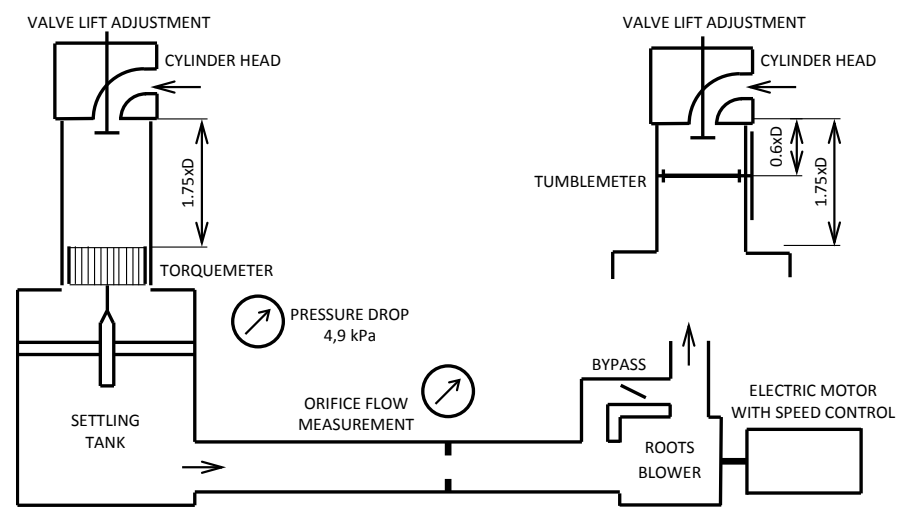

FIGURE 2: Measurement of discharge coefficient, swirl and tumble scheme of experimental setup.

OBRÁZEK 2: Měření průtokového součinitele, tečné a přičné rotace schéma experimentálního stanoviště.
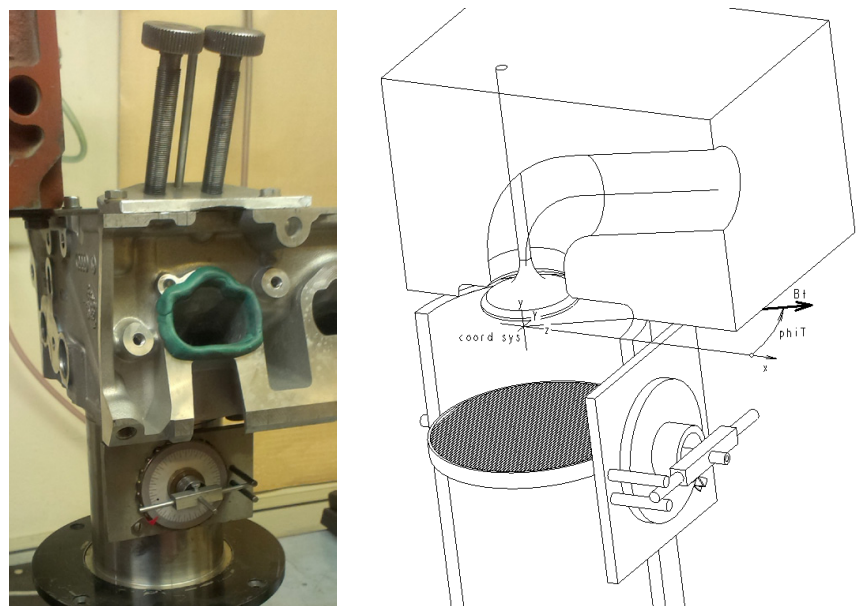

FIGURE 3: Experimental setup location of tumblemeter and its scheme of principle operation.

OBRÁZEK 3: Poloha zařízení pro měření příčné rotace a jeho schéma z hlediska funkčního principu. 
The tumble number with similar definition is calculated:

$\frac{n_{j p}}{n}=\frac{2 \cdot \rho \cdot Z \cdot B_{T}}{\dot{m}_{\text {meas }}^{2}}$

Where $B_{T}$ is angular momentum flux of tumble measured by tumblemeter. For better comparison of results between different engines (in terms of design), a reduced ratios are defined:

$$
\left(\frac{n_{j t}}{n}\right)_{r}=\left(\frac{n_{j t}}{n}\right) \cdot \frac{D}{Z} \quad\left(\frac{n_{j p}}{n}\right)_{r}=\left(\frac{n_{j p}}{n}\right) .
$$

This definition reduces the above-mentioned swirl and tumble ratios to the case of engine with 'square' design (bore equals stroke).

The measured data are labeled as 'exp. data' in all figures below - green dashed line usually corresponds to experimental results.

\section{COMPUTED CASES}

The same cases, which were measured, were calculated by means of 3-D CFD SW tool AVL FIRE [14]. Moreover, most of them were calculated using all 3 turbulence modeling approaches (RANS, LES and PANS). As it is mentioned above, relative valve lift variation between 0 and $100 \%$ was considered. There were 2 different configurations - the first one corresponds to normal ICE operation as both intake valves are open simultaneously (figure label: 'both intake valves open'). The second one regards unconventional SI engine operation (dominated by high swirling motion) which requires that only single valve is open while the other one is permanently closed (figure label: 'single intake valve open'). The following parameters were evaluated from simulation results to be compared with experimental data: flow coefficient, swirl number and tumble number.

Initially, the default setting of boundary layer setup was used this means 3 boundary layers, each of them measuring $0.1 \mathrm{~mm}$ in direction perpendicular to the wall. However, it was found that these 2 parameters have significant influence on the results. Based on discussions with AVL CFD experts, it was decided to increase the number of boundary layers to 4 and the height of single layer was varied between 0.06 and $0.15 \mathrm{~mm}$. Hence, the label 'BL' denotes boundary layer of the mesh (i.e. not the real boundary layer of the flow).

Certain parameters of numerical model setting were tested (time accuracy of numerical scheme, differencing scheme of convection terms, linear solver convergence setting, global convergence setting, etc.), however only very small influence was observed.

\section{DISCUSSION OF RESULTS}

After initial CFD results had been analyzed, it was found out that mass flow rate (flow coefficient) was significantly different when compared with experimental data. Interestingly, this related to 'classical' case of both intake valves open - regarding the 'unconventional' case of single intake valve open, the correspondence with measured data was good. Based on these initial results and discussions with SW provider, it was decided to run certain sensitivity studies to improve quality of simulated data. Moreover, all these sensitivity studies were carried out for the 'classical' configuration (both intake valves open) only once the best parameters of the calculation were determined, the same setting was applied to the 'unconventional' case (single intake valve open) to confirm the result quality.

The Figure 4 shows the influence of time accuracy of applied numerical scheme (either $1^{\text {st }}$ or $2^{\text {nd }}$ order) at 2 different levels of BL thickness. As expected, the time accuracy has almost no effect. On the other hand, thickness of $\mathrm{BL}$ is relatively significant - that is why the focus was set to this parameter.

The next test dealt with the amount of BLs and their thickness while considering different versions of LES turbulence model (dynamic LES-CSM and standard Smagorinsky LES) - c.f. Figure 5. The results confirm the trend that both BL thickness and amount of BLs are important parameters in terms of mass flow rate. After discussions with experts from SW provider, it was decided to keep the amount of BLs at 4. The Figure 5 also shows the fact that higher BL thickness leads to higher mass flow - this is confirmed by other figures as well (Figure 8 and 10). Based on all these facts, the BL thickness can be considered as a tuning parameter in terms of mass flow rate. The influence of typical mesh cell size (considering LES and PANS turbulence models, and different time accuracy schemes) is shown in Figure 6. Surprisingly, there is very little influence of the cell size although the fine mesh (cell size $0.3 \mathrm{~mm}$ ) has approx. 3-times more cells than the standard mesh (cell size $0.6 \mathrm{~mm}$ ). As the trend is the same for both LES and PANS, it leads to conclusion that even if

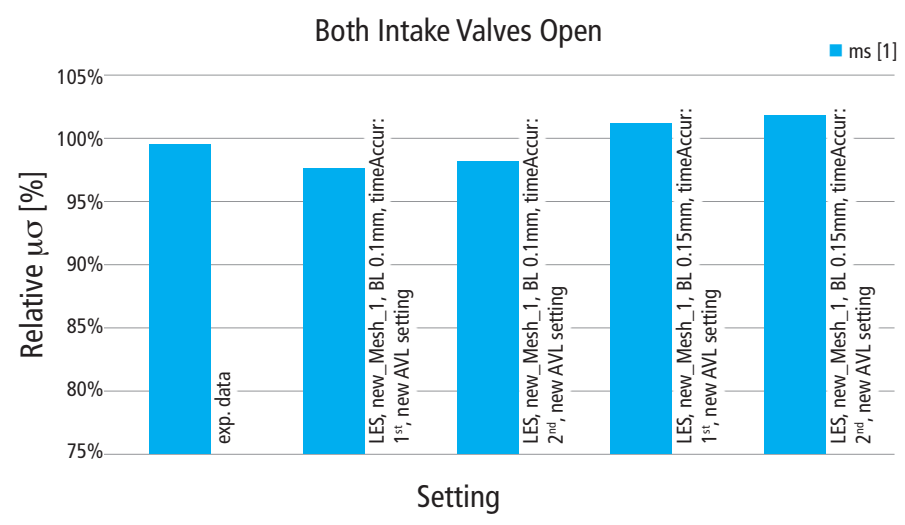

FIGURE 4: Flow coefficient - influence of BL thickness and numerical accuracy in time domain (turbulence model: LES; amount of BLs: 3) at valve lift of $55 \%$ - the case of both intake valves being opened. OBRÁZEK 4: Průtokový součinitel - vliv tlouštky sítě u stěny and numerické přesnosti v časové doméně (model turbulence: LES; počet vrstev stěnových buněk: 3) pro zdvih ventilu $55 \%$ - varianta se dvěma otevřenými sacími ventily. 


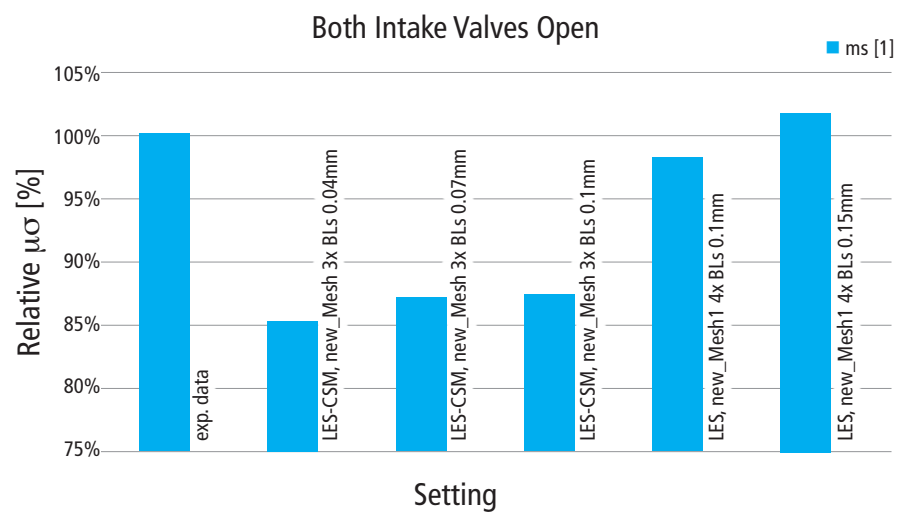

FIGURE 5: Flow coefficient - influence of BL thickness for 3 and 4 layers of BL (turbulence model: LES) at valve lift of $55 \%$ - the case of both intake valves being opened.

OBRÁZEK 5: Průtokový součinitel - vliv tloušt́ky sítě u stěny pro 3 a 4 vrstvy těchto stěnových buněk (modelu turbulence: LES) pro zdvih ventilu $55 \%$ - varianta se dvěma otevřenými sacími ventily.

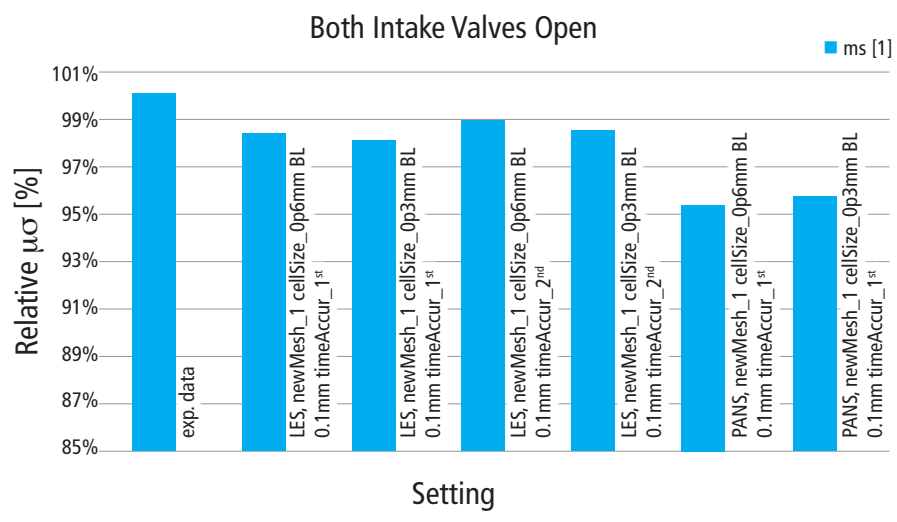

FIGURE 6: Flow coefficient - influence of typical mesh cell size (turbulence models: LES and PANS; amount of BLs: 4) at valve lift of $55 \%$ - the case of both intake valves being opened.

OBRÁZEK 6: Průtokový součinitel - vliv typické velikosti oka sítě (modely turbulence: LES a PANS; počet vrstev stěnových buněk: 4) pro zdvih ventilu $55 \%$ - varianta se dvěma otevřenými sacími ventily.

cell size of $0.3 \mathrm{~mm}$ is considered, it is still not fine enough for LES to resolve important scales in the area between the vale and the valve seat. Moreover, it is well-know that LES performance is poor near the walls (boundary layer) - it seems that these effects are important in the considered cases. That is confirmed by data shown in Figure 7, which shows a ratio of modelled and total turbulence kinetic energy (this information is only available when the PANS approach is applied) - it is shown for both standard mesh (cell size $0.6 \mathrm{~mm}$ ) and fine mesh (cell size $0.3 \mathrm{~mm}$ ). If well-resolved LES simulation is to be performed, this ratio should be below the value of 0.3. Unfortunately, this is not the case for the standard mesh in the majority of the combustion chamber. Moreover, the ratio is still too high even for the case of the fine mesh - this mainly concerns the valve seat region and the area downstream of the intake valve.
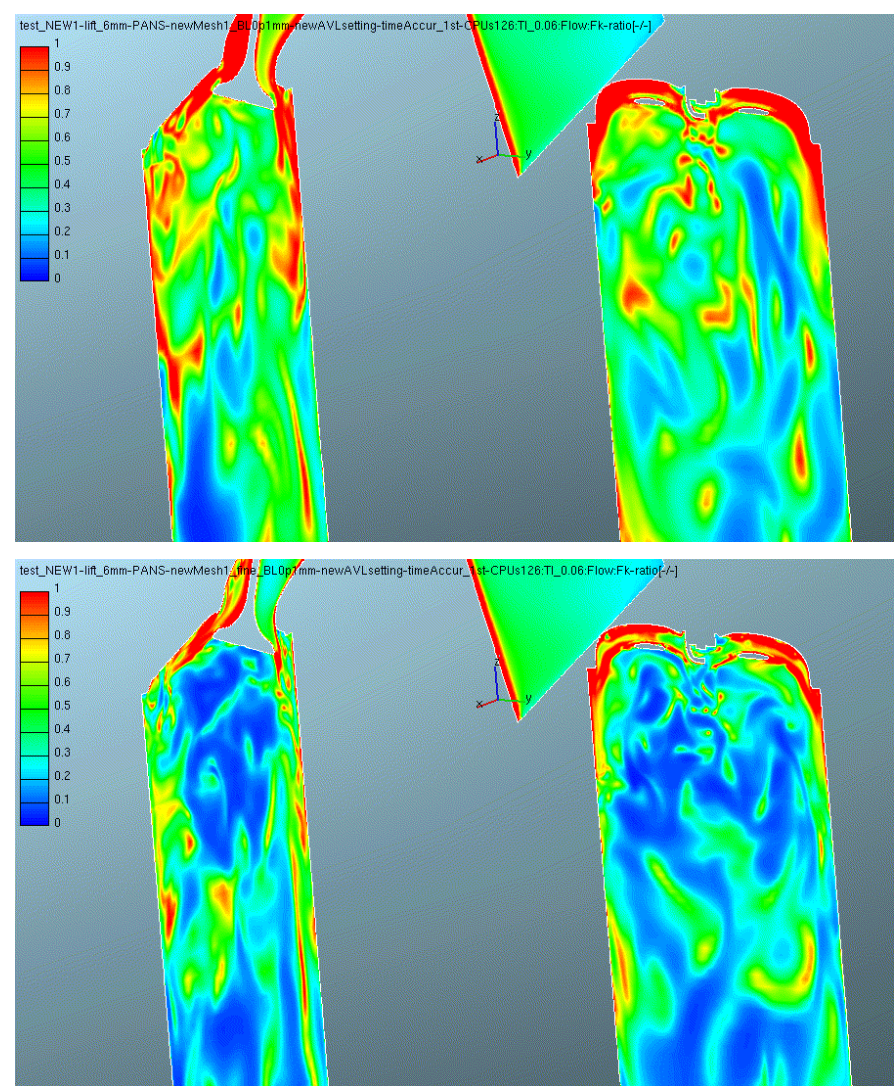

FIGURE 7: Ratio of modeled and total turbulence kinetic energy plotted in 2 perpendicular sections of considered ICE (turbulence model: PANS; amount of BLs: 4; BL thickness: $0.1 \mathrm{~mm}$ ) at valve lift of $6 \mathrm{~mm}$ - the case of both intake valves being opened. Top subfigure corresponds to the case of cell size of $0.6 \mathrm{~mm}$ (standard mesh), bottom subfigure concerns the case of cell size of $0.3 \mathrm{~mm}$ (fine mesh). The presented data are related to Figure 6.

OBRÁZEK 7: Poměr mezi velikostí modelované a celkové turbulentní kinetické energie ve dvou na sebe kolmých řezech uvažovaného motoru (model turbulence: PANS; počet vrstev stěnových buněk: 4; tloušt'ka stěnových buněk: $0.1 \mathrm{~mm}$ ) $6 \mathrm{~mm}$ - varianta se dvěma otevřenými sacími ventily. Horní obrázek odpovídá prípadu s velikostí sítě $0.6 \mathrm{~mm}$ (standardní sít'), dolní obrázek zobrazuje prípad s velikostí sítě $0.3 \mathrm{~mm}$ (jemná sít). Zobrazená data odpovídají Obrázku 6.

Hence, the poor LES performance is a logical consequence of that. Although LES was considered in the other tests, it was expected that PANS would provide the best performance combining advantages of both LES and RANS.

The influence of BL thickness is plotted in Figure 8. Figure 9 and Figure 10 for both LES and PANS. From qualitative point of view, the trend is the same - as BL thickness is increased, mass flow rate increases as well. Moreover, saturation at low BL thickness levels is observed - it seems that too low value of BL thickness (below $0.06 \mathrm{~mm}$ ) has little influence on mass flow. Saturation is also observed for the LES case at high levels of BL thickness, however this is not seen for PANS. Based on these results, the optimal value of BL thickness is $0.08 \mathrm{~mm}$ for LES and $0.15 \mathrm{~mm}$ for PANS. The results concerning dynamic LES model (LES-CSM) 


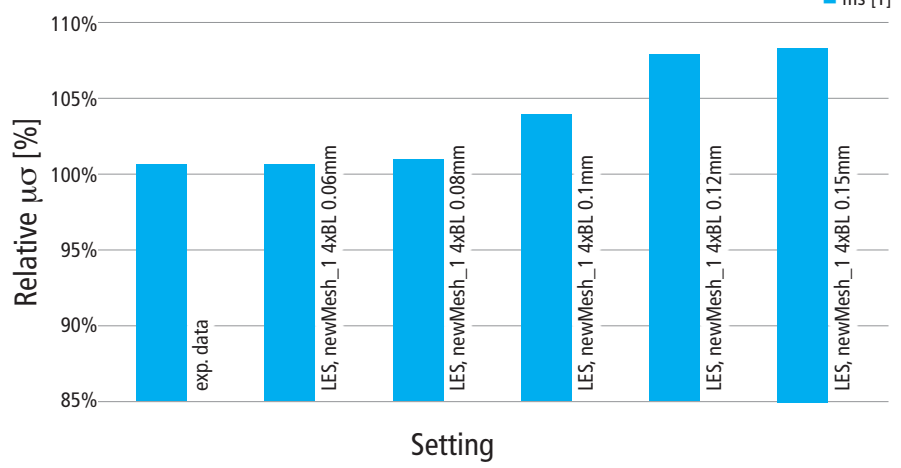

FIGURE 8: Flow coefficient - influence of BL thickness (turbulence model: LES; amount of BLs: 4) at valve lift of $82 \%$ - the case of both intake valves being opened.

OBRÁzEK 8: Průtokový součinitel - vliv tlouštky sítě u stěny pro zdvih ventilu (model turbulence: LES; počet vrstev stěnových buněk: 4) 82 \% varianta se dvěma otevřenými sacími ventily.

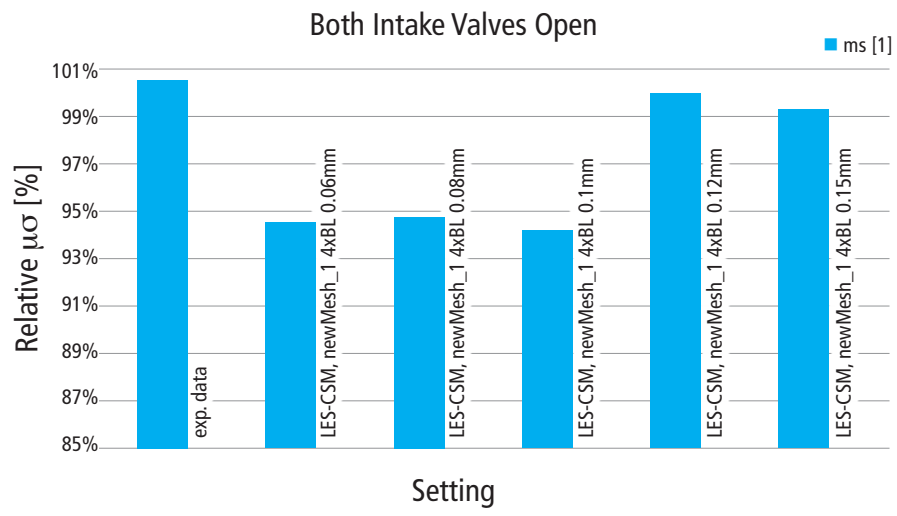

FIGURE 9: Flow coefficient - influence of BL thickness (turbulence model: LES-CSM; amount of BLs: 4) at valve lift of $82 \%$ - the case of both intake valves being opened.

OBRÁZEK 9: Průtokový součinitel - vliv tloušt'ky sítě u stěny pro zdvih ventilu (model turbulence: LES-CSM; počet vrstev stěnových buněk: 4) $82 \%$ - varianta se dvěma otevřenými sacími ventily.

are not exactly the same as for LES (standard Smagorinsky) and PANS - c.f. Figure 9. The trend is not monotonic and it seems a bit strange - this might related to the fact that the mesh is not fine enough for proper LES. It is interesting to note that the optimal BL thickness value is so different when comparing LES and PANS. Regarding the influence of BL parameters on tumble ratio, the following can be stated (c.f. Figure 11). As expected, the influence is very limited - if mass flow is changed, the relative flow distribution.in space remains (almost) unchanged, hence the tumble/swirl ratio is expected to be (almost) unaffected. However, space flow pattern is not exactly the same, hence small influence of tumble/swirl ratio is expected. The mass flow rate changes are within few percent (c.f. Figure 10) and the similar changes are observed for tumble ratio as well (c.f. Figure 11).

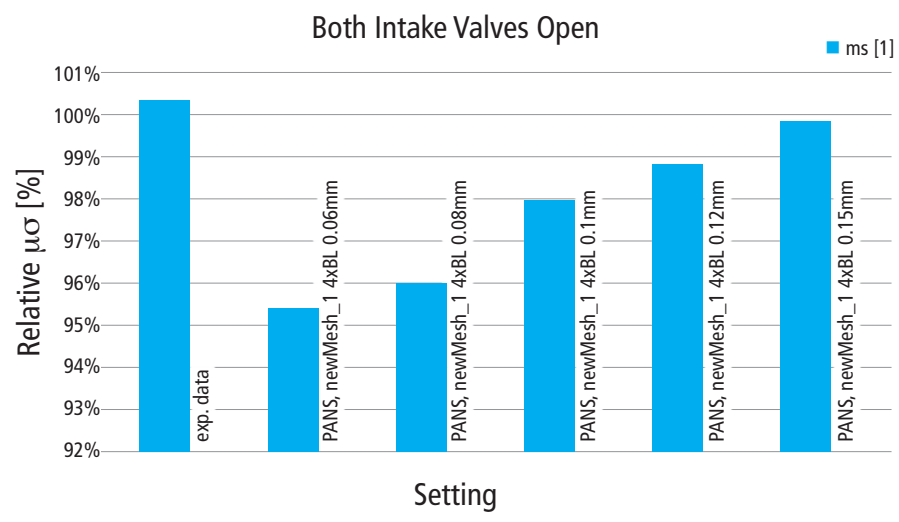

FIGURE 10: Flow coefficient - influence of BL thickness (turbulence model: PANS; amount of BLs: 4) at valve lift of $82 \%$ - the case of both intake valves being opened.

OBRÁZEK 10: Průtokový součinitel - vliv tlouštky sítě u stěny pro zdvih ventilu (model turbulence: PANS; počet vrstev stěnových buněk: 4) $82 \%$ varianta se dvěma otevřenými sacími ventily.

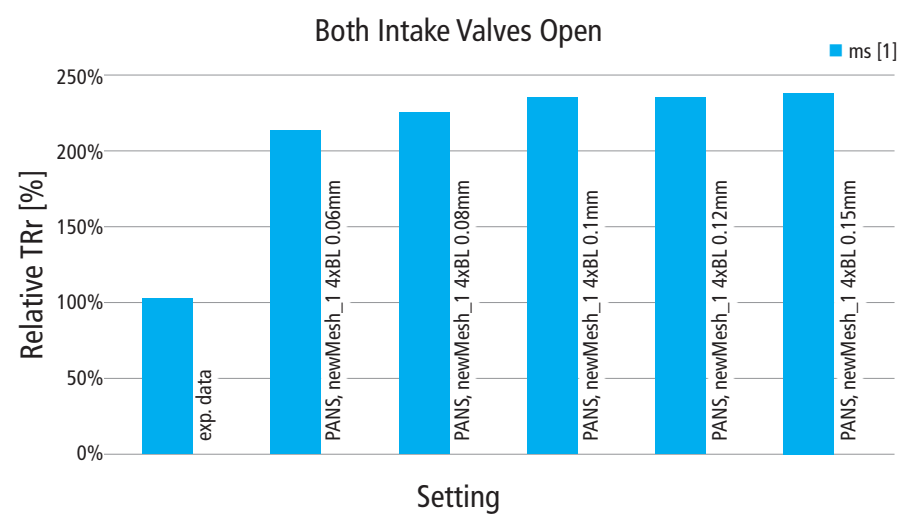

FIGURE 11: Reduced tumble ratio - influence of BL thickness (turbulence model: PANS; amount of BLs: 4) at valve lift of $82 \%$ - the case of both intake valves being opened.

OBRÁZEK 11: Redukované číslo příčné rotace - vliv tloušt'ky sítě u stěny pro zdvih ventilu (model turbulence: PANS; počet vrstev stěnových buněk: 4) $82 \%$ - varianta se dvěma otevřenými sacími ventily.

Finally, the dependency of mass flow rate and tumble/swirl ratio on valve lift is presented - the swirl ratio is shown only for the case of single intake valve being opened (due to symmetry, the average swirl ratio is zero for the case of both intake valves being opened). The case of LES and default BL thickness $(0.1 \mathrm{~mm})$ is shown in Figure 12 and Figure 13. Concerning the mass flow rate, there is overprediction of maximum rate and the shape at high valve lift region is slightly different. Regarding tumble ratio, the correspondence with experimental data is poor - the value is too low at low valve lifts while is it significantly higher at high valve lift region. Moreover, the qualitative correspondence (the curve shape) is not satisfactory. Unfortunately, this trend is observed for all the tested cases (regardless of turbulence model and/or BL properties). Hence, the root cause of that is not related to factors, which were commented above - it seems 
Both Intake Valves Open

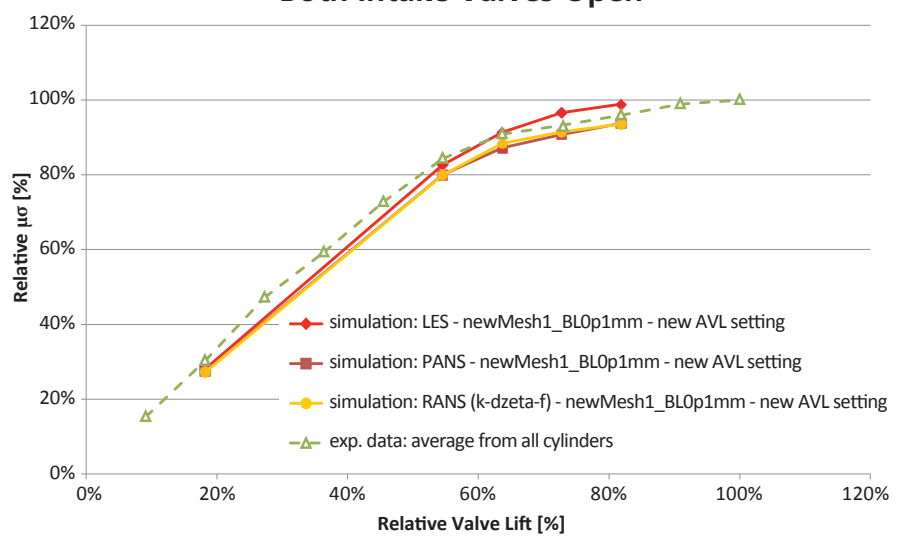

FIGURE 12: Flow coefficient - dependence on valve lift (different turbulence models; amount of BLs: 4; BL thickness: $0.1 \mathrm{~mm}$ ) - the case of both intake valves being opened.

OBRÁZEK 12: Průtokový součinitel - závislost na zdvihu ventilu (různé modely turbulence; počet vrstev stěnových buněk: 4; tloušt'ka stěnových buněk: $0.1 \mathrm{~mm}$ ) - varianta se dvěma otevřenými sacími ventily.

\section{Both Intake Valves Open}

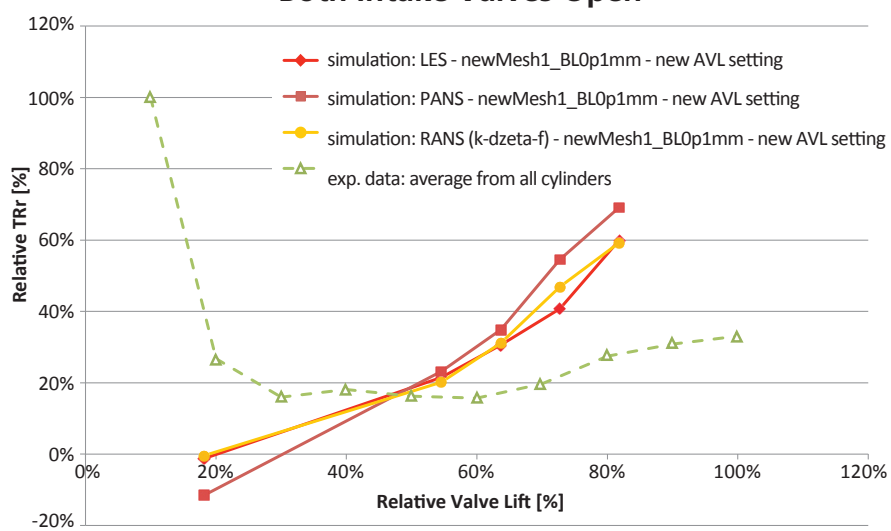

FIGURE 13: Reduced tumble ratio - dependence on valve lift (different turbulence models; amount of BLs: 4; BL thickness: $0.1 \mathrm{~mm}$ ) - the case of both intake valves being opened.

OBRÁZEK 13: Redukované číslo príčné rotace - závislost na zdvihu ventilu (různé modely turbulence; počet vrstev stěnových buněk: 4; tloušt'ka stěnových buněk: $0.1 \mathrm{~mm}$ ) - varianta se dvěma otevřenými sacími ventily.

that the main reason of that has to be another phenomenon. This is discussed in more detail in the Conclusion section. When optimal value of $B L$ thickness is applied for the LES case, the correspondence with experimental data is actually worse - c.f. Figure 14 and Figure 15. As the model tuning (search for optimal BL thickness) was done at relative valve lift of $82 \%$, the mass flow rate at this valve lift is OK. However, the mass flow rate at slightly lower lifts is higher than the measured one, moreover it is even higher than the value at max. valve lift. Hence, the predicted mass flow rate curve is not monotonically increasing which is obviously a wrong trend. This again confirms poor performance of LES approach.

The results concerning PANS approach at default BL thickness is presented in Figure 12 and Figure 13 The trend of mass flow rate
Both Intake Valves Open

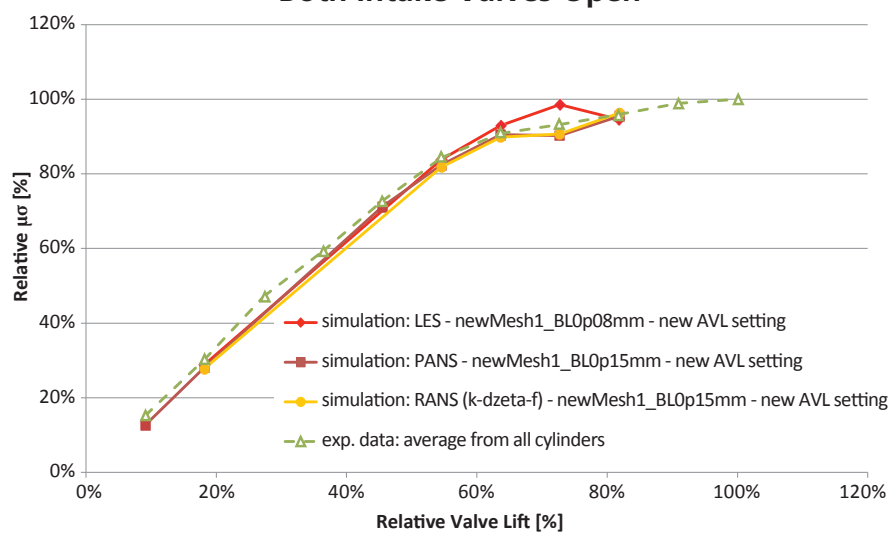

FIGURE 14: Flow coefficient - dependence on valve lift (different turbulence models; amount of BLs: 4; optimal BL thickness) - the case of both intake valves being opened.

OBRÁzEK 14: Průtokový součinitel - závislost na zdvihu ventilu (různé modely turbulence; počet vrstev stěnových buněk: 4; optimální tloušt'ka stěnových buněk) - varianta se dvěma otevřenými sacími ventily.

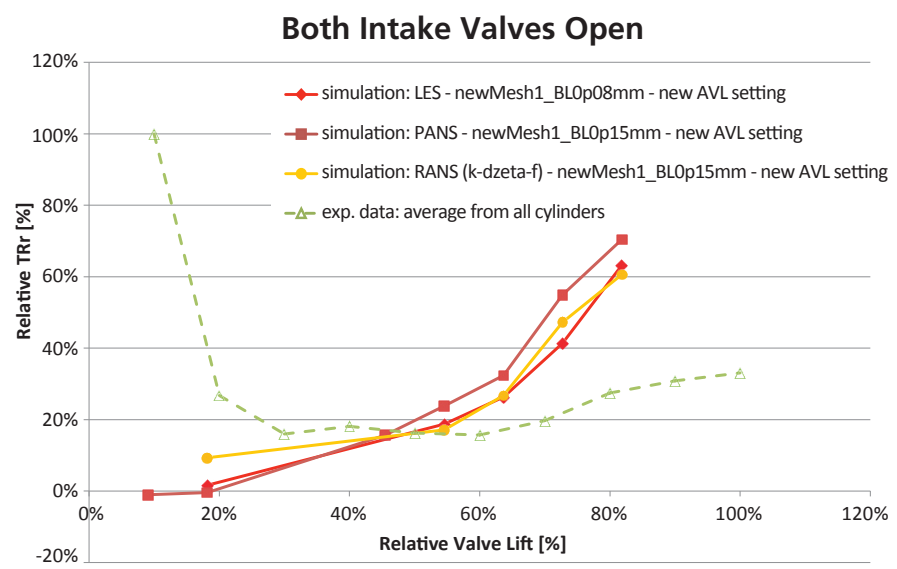

FIGURE 15: Reduced tumble ratio - dependence on valve lift (different turbulence models; amount of BLs: 4; optimal BL thickness) - the case of both intake valves being opened.

OBRÁZEK 15: Redukované číslo příčné rotace - závislost na zdvihu ventilu (různé modely turbulence; počet vrstev stěnových buněk: 4; optimální tlouštka stěnových buněk) - varianta se dvěma otevřenými sacími ventily.

is OK while the predicted data are slightly below the measured value. Regarding tumble ratio, the same can be states as for the LES case above - the qualitative trend is wrong. The predicted data, which concern optimal BL thickness of PANS case, are shown in Figure 14 and Figure 15. The mass flow rate prediction is improved while tumble ratio remains unaffected. There is little decrease of calculated mass flow rate at the valve lift of $73 \%$. Detailed analysis of this particular case shows that the instantaneous data are relatively strongly oscillatory - it is clearly more than for relative valve lifts of $64 \%$ and $82 \%$. Due to dynamic nature of turbulence, all the results show instantaneous oscillations of mas flow rate (this concerns all turbulence models - LES, PANS and RANS - due to small cell size of the mesh). Hence, all the presented results are 
Single Intake Valve Open

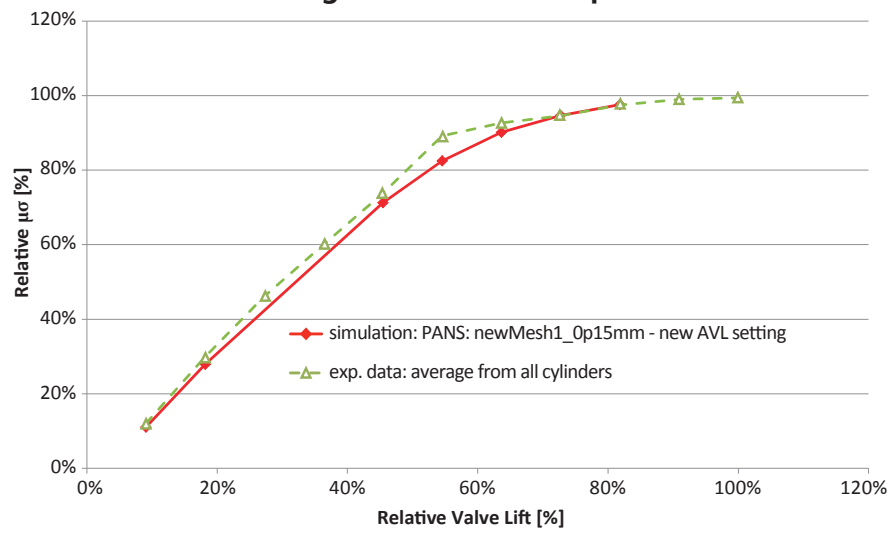

FIGURE 16: Flow coefficient - dependence on valve lift (turbulence model: PANS; amount of BLs: 4; BL thickness: $0.15 \mathrm{~mm}$ ) - the case of both intake valves being opened.

OBRÁzEK 16: Průtokový součinitel - závislost na zdvihu ventilu (model turbulence: PANS; počet vrstev stěnových buněk: 4; tlouštka stěnových buněk: $0.15 \mathrm{~mm}$ ) - varianta s jedním otevřeným sacím ventilem.

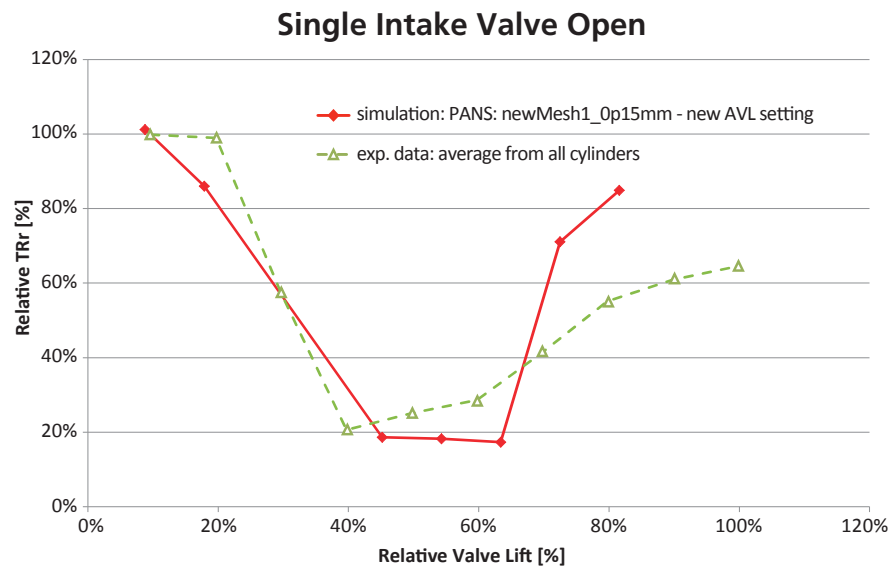

FIGURE 17: Reduced tumble ratio - dependence on valve lift (turbulence model: PANS; amount of BLs: 4; BL thickness: $0.15 \mathrm{~mm}$ ) - the case of single intake valves being opened.

OBRÁZEK 17: Redukované číslo příčné rotace - závislost na zdvihu ventilu (model turbulence: PANS; počet vrstev stěnových buněk: 4; tlouštka stěnových buněk: $0.15 \mathrm{~mm}$ ) - varianta s jedním otevřeným sacím ventilem.

averaged using relatively long time period to guarantee statistical convergence of the calculation. However, this particular case (valve lift of $73 \%$ for PANS at BL thickness of $0.15 \mathrm{~mm}$ ) exhibits clearly higher oscillations when compared with other cases. It is believed that the weaker flow stability of this case might be responsible for small decrease of mass flow rate.

The data regarding the RANS case at default BL thickness $(0.1 \mathrm{~mm})$ are presented in Figure 12 and Figure 13. They show very similar trend as the case of PANS at default BL thickness. This was expected as the mesh cell size is not fine enough for proper LES, hence PANS performs more like RANS. That also confirms good performance of RANS in terms of mass flow rate. However, it should be stressed that applied mesh (typical mesh cell size of $0.6 \mathrm{~mm}$ ) was mainly intended

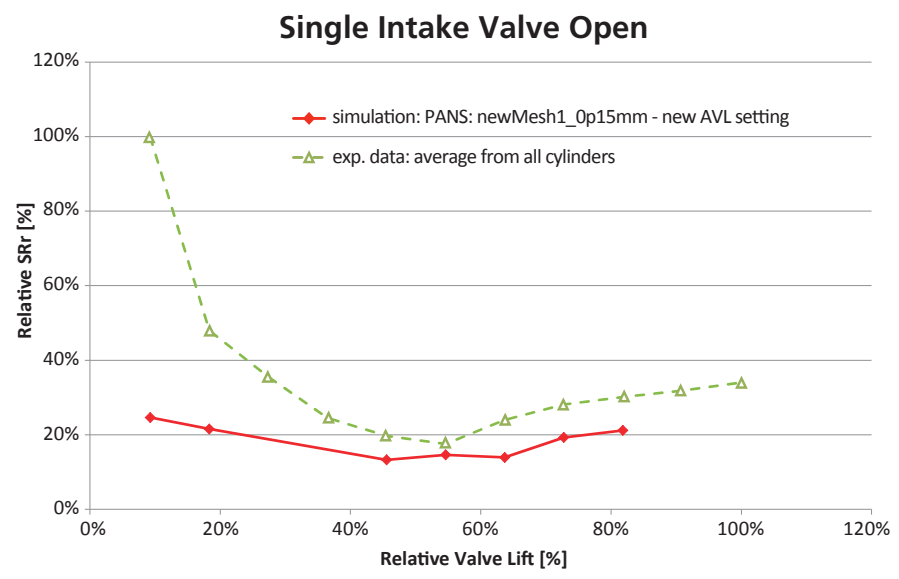

FIGURE 18: Reduced swirl ratio - dependence on valve lift (turbulence model: PANS; amount of BLs: 4; BL thickness: $0.15 \mathrm{~mm}$ ) - the case of single intake valves being opened.

OBRÁZEK 18: Redukované čislo tečné rotace - závislost na zdvihu ventilu (model turbulence: PANS; počet vrstev stěnových buněk: 4; tlouštka stěnových buněk: $0.15 \mathrm{~mm}$ ) - varianta s jedním otevřeným sacím ventilem.

for LES/PANS simulation, hence it might be too fine for RANS - in other words, the mesh resolution can be coarser for RANS without deterioration of the results. Due to that, simulation duration of RANS is significantly longer than that of LES. As RANS performance is very close to PANS one due to mesh size, it is expected that RANS at BL thickness of $0.15 \mathrm{~mm}$ would perform very similarly as PANS at this BL value - this is confirmed in Figure 14 and Figure 15.

The best variant (PANS, 4 BLs, BL thickness $0.15 \mathrm{~mm}$ ) was applied to the case of single valve being opened - the results are shown in Figure 16, Figure 17 and Figure 18. The mass flow rate is well captured with the exception of the value at valve lift of $54 \%$. Unfortunately, this feature was observed in all tested variants. Regarding tumble ratio, the following can be stated - the trend is captured relatively well concerning both quality and quantity. Concerning the swirl ratio, the qualitative trend is similar to the one of measured data, however the predicted value is significantly lower - this is especially true for low valve lift region. The significant difference between predicted swirl ratio and measured data was observed for all tested variants.

\section{CONCLUSION}

The paper deals with modeling of steady flow test bench of automotive engine intake channels. Two different configurations were considered - the classical case of both intake valves being opened and the unconventional one of single intake valve being opened. As expected, the former configuration results in tumbling motion only while the latter one leads to formation of relatively strong swirl and tumble.

The results were obtained by means of both measurement and 3-D CFD simulation, hence comparison of both approaches 
was performed. Regarding the simulation, different cases were considered regarding the BL configuration (amount of layers and layer thickness), mesh cell size and turbulence models.

First, influence of BL was tested - the term BL concerns the layers of mesh near the wall (BL means boundary layer of the mesh) to capture the effect of the wall - however it does not necessarily mean that flow boundary layer is properly modeled. BL configuration is an important parameter - both thickness (of single layer) and amount of these layers have relatively strong influence on predicted mass flow rate, however tumble/swirl coefficient is little affected by that. That suggests that important phenomena take place in the BL mesh regions, which influence the total mass flow rate. Hence, boundary layer of the flow (in the region between a valve and a valve seat) is important in terms of gas exchange phase of ICE. From modelling point of view, BL configuration can be understood as a tuning parameter. This might be advantage as the user has the ability to adjust the results. On the other hand, it is disadvantage from general point of view in terms of 3-D CFD - this detailed modeling approach is supposed to be general enough so there should not be a need for tuning parameter(s).

The above mentioned influence of BL configuration may call for a finer mesh to sufficiently resolve important flow structures. Hence, the influence of mesh cell size was tested - fine mesh was created (typical cell size of standard mesh was $0.6 \mathrm{~mm}$ while this value of fine mesh was $0.3 \mathrm{~mm}-$ c.f. Table 2 for more detailed information regarding the considered meshes). Although it has approximately 3-times more cells while the BL configuration was the same as for the standard mesh, almost no improvement was observed in terms of mass flow rate. Different turbulence models (LES and PANS) were tested for that. The more detailed analysis of resolved turbulence kinetic energy suggests significant improvement for the case of the fine mesh (when compared with the standard mesh), however even finer mesh refinement is probably needed to perform proper LES.

Regarding the turbulence models, the following ones were tested - LES (2 versions: standard Smagorinsky one and dynamic one), PANS and RANS. As expected, the LES performance was relatively poor. There are 2 reasons for that - it is well-known that the flow prediction in boundary layer is a problem for LES, moreover it seems that the mesh size (even in the case of the fine mesh) is still not fine enough to properly resolve the turbulent flow structures near the valve (especially in the valve seat region and flow separation region just downstream of the valve stem). Performance of PANS and RANS was very similar - this is most likely related to the above mentioned fact that the mesh resolution is not fine enough for correct LES, hence PANS actually performs as RANS. In terms of mas flow prediction, even at default BL thickness $(0.1 \mathrm{~mm})$ the performance of all turbulence models is similar - the relative error is typically below $5 \%$, which is a reasonable number when these data (dependency of valve flow coefficient on valve lift) are applied in a system simulation SW tools (e.g., 0-D/1-D SW [15]). After tuning
BL thickness, PANS and RANS prediction matched the measured data well. It was not possible to achieve such a good result for the LES approach.

Generally, the prediction of swirl/tumble ratio is poor regardless of mesh cell size, BL configuration or applied turbulence model - the only exception is tumble ratio for the case of single valve being opened. This suggests that flow distribution in the cylinder is different (when compared with experimental evidence). Moreover, there is one phenomenon which might be very important - the experimental data are based on torque measurement while the calculated data are derived from momentum fluxes. Especially in the case of tumble, it is not obvious that the momentum flux is captured properly by the tumblemeter (due to dependence of its drag coefficient on Reynolds number) - that may explain differences between measured and predicted data. Hence, there is a certain inconsistency between measurement methodology and simulation methodology in terms of evaluation of tumble/swirl ratio. It may not be so simple to deal with that issue - to be sure that the evaluated tumble/swirl ratio is consistent (between experiment and simulation), a model of the measuring device (e.g., tumblemeter) would have to be created to calculate the torque value. Hence, the future work will be aimed at that - there is an experimental evidence of local drag coefficient dependency (of the tumblemeter material) on Reynolds number. Although the simplified model of the measuring device may not be very precise, it should be possible to get some reasonable estimate of torque value - then this value can be compared with experimental data to provide more consistent comparison between the simulation and the experiment.

\section{ACKNOWLEDGEMENTS}

This research has been realized using the support of Technological Agency, Czech Republic, programme Centres of Competence, project TE01020020: 'Josef Božek Competence Centre for Automotive Industry'.

This research has been realized using the support of EU Regional Development Fund in OP R\&D for Innovations (OP VaVpl) and The Ministry of Education, Youth and Sports, Czech Republic, project CZ.1.05/2.1.00/03.0125: 'Acquisition of Technology for Vehicle Center of Sustainable Mobility'.

This research has been realized using the support of The Ministry of Education, Youth and Sports program NPU I (LO), project L01311: 'Development of Vehicle Centre of Sustainable Mobility'.

All the help has been gratefully appreciated.

\section{LIST OF NOTATIONS AND ABBREVIATIONS}

BL Boundary Layer (of mesh near the wall)

CFD Computation Fluid Dynamics

DNS Direct Numerical Solution

ICE Internal Combustion Engine 
LES-CS Mdynamic version of LES model

PANS Partially Averaged Navier-Stokes (equation set)

RANS Reynolds Averaged Navier-Stokes (equation set)

SW Software

\section{REFERENCES}

[1] Hanjalic K., Popovac M., Hadziabdic M. (2004). A Robust Near-Wall Elliptic-Relaxation Eddy-Viscosity Turbulence Model for CFD, In: International Journal of Heat and Fluid Flow, Vol. 25, pp. 1047-1051.

[2] Popovac M., Hanjalic K. (2007). Compound Wall Treatment for RANS Computation of Complex Turbulent Flows and Heat Transfer, In: Flow, Turbulence, and Combustion, Vol. 78, pp. 177-202.

[3] Basara B. (2006). An Eddy Viscosity Transport Model Based on Elliptic Relaxation Approach, In: AIAA Journal, Vol. 44, pp. 1686-1690.

[4] Smagorinsky J. (1963). General Circulation Experiments with the Primitive Equations, In: Mon. Weather Rev., Vol. 91(3):99-164.

[5] Deardorff J. (1970). A numerical study of three-dimensional turbulent channel flow at large Reynolds numbers. In: Journal of Fluid Mechanics., Vol. 41 (2): 453-480, doi:10.1017/S0022112070000691.

[6] Lesiuer M., Metais O., Comte P. (2005). Large-eddy simulation of turbulence, Cambridge University Press, ISBN-10 0-521-78124-8.

[7] Kobayashi H. (2005). The subgrid-scale models based on coherent structures for rotating homogeneous turbulence and turbulent channel flow. In: Physics of Fluids, Vol. 17.

[8] Kobayashi H., Ham F., and Wu X. (2008). Application of a local SGS model based on coherent structures to complex geometries. In: Int. J. of Heat and Fluid Flow, Vol. 29., pp. 640-653.

[9] Girimaji S. (2006). Partially-averaged Navier-Stokes model for turbulence: a RANS to DNS bridging method, In: ASME Journal of Appl. Mechanics, Vol. 73(5): 413-421.

[10] Basara B., Krajnovic S., Girimaji S. and Pavlovic, Z. (2011). Near-Wall Formulation of the Partially Averaged NavierStokes Turbulence Model. In: AIAA Journal, Vol. 49(12), pp. 2627-2636.

[11] Lakshmipathy S., and Girimaji S. (2006). Partially-Averaged Navier-Stokes Method for Turbulent Flows: $k-\omega$ model Implementation. In: AIAA Aerospace Sciences Meeting and Exhibition, Reno, Nevada, 2006-119

[12] Pera C., Angelberger C. (2011). Large Eddy Simulation of a Motored Single-Cylinder Engine Using System Simulation to Define Boundary Conditions: Methodology and Validation, IN: SAE Int. J. Engines 4(1):948-963, doi: 10.4271/2011-01-0834.

[13] Vitek O., Macek J., Tatschl R., Pavlovic Z. et al. (2012). LES Simulation of Direct Injection SI-Engine In-Cylinder Flow. SAE Technical Paper 2012-01-0138, doi:10.4271/2012-01-0138.

[14] AVL AST (2013). FIRE Manual v2013, AVL List GmbH, Graz. [15] GT-Power User's Manual, GT-Suite version 7.3. Gamma Technologies Inc., 2012.

\section{APPENDIX}

\section{A. LES}

The idea of LES is relatively old and it comes from external aerodynamics - it based on assumption that large-scale turbulence structures, which carry most of turbulence energy, are generally non-isotropic and their non-linear interaction is responsible for many important turbulence properties (e.g., enhanced scalar transport, general un-steadiness). It is clearly difficult to model them in RANS approach - the whole turbulent spectrum of scales is modeled when using RANS. In the LES case, these large-scale turbulent structures are captured by the simulation itself while the smaller ones, which are more isotropic and generally dissipative in their nature, are modeled by LES sub-grid scale (SGC) models, which is easier to do when compared with RANS. The penalty of LES is that the mesh has to be significantly finer so that these large turbulent eddies are properly captured - this leads to substantial increase in computation times, however parallelization approach allows to minimize this negative effect. Details regarding the LES approach can be found in $[4,5,6,7,8,14]$.

\section{B. PANS}

The PANS approach is a bridging method between RANS and LES (or even DNS) which is based on typical RANS formulation - it can be considered as a hybrid RANS/LES method. Depending on filter width (i.e., mesh size) and other criteria, it selects between the RANS approach and the LES one. One of other important criteria is resolved turbulence kinetic energy - if the ratio of that (resolved turbulence kinetic energy) and total turbulence kinetic energy (estimated by k-equation of RANS model) is low enough, LES/DNS approach is applied. Otherwise RANS approach is used. It seems that PANS approach can minimize sensitivity of LES approach with respect to mesh size to properly capture largescale turbulence structures - it uses RANS approach in the mesh region where the mesh is not fine enough to capture these turbulence structures. However, one of possible disadvantages is that PANS (as it is implemented in [14]) can be applied to steady cases from statistical point of view (e.g., steady flow test bench) - it will not work properly if unsteady case is considered. Details regarding the PANS approach can be found in $[9,10,11]$. 